\title{
Die vier Nicaanse merktekens van die kerk as rigtingwysers in ' $n$ ekklesiologiese diskoers
}

\begin{abstract}
Authors:
M.E. Schalekamp

B.J. de Klerk ${ }^{1}$

Affiliations:

${ }^{1}$ Department of Practical

Theology, Potchefstroom

Campus, North-West

University, South Africa

Correspondence to:

Etienne Schalekamp

Email:

meschal@mweb.co.za

Postal address:

PO Box 7670, Westgate 1734,

South Africa

Dates:

Received: 15 Apr. 2010

Accepted: 30 Sept. 2010

Published: 26 Nov. 2012

How to cite this article: Schalekamp, M.E. \& De Klerk, B.J., 2012, 'Die vier Nicaanse Merktekens van die kerk as rigtingwysers in 'n ekklesiologiese diskoers', In die Skriflig/In Luci Verbi 46(2), Art. \#104, 9 pages. http://dx.doi.org/10.4102/ ids.v46i2.104
\end{abstract}

C 2012. The Authors. Licensee: AOSIS OpenJournals. This work is licensed under the Creative Commons Attribution License.
Die ondersoek het rondom die vier begrippe in die Geloofsbelydenis van Nicea gesentreer, naamlik eenheid, heiligheid, katolisiteit en apostolisiteit. Die vraag wat nagegaan was, is of hierdie vier merktekens kan dien as riglyne in 'n ekklesiologiese diskoers. In die artikel was eerstens aandag gegee aan die Belydenis van Nicea oor die merktekens van die kerk, daarna was nagevors of die vier merktekens reeds in beginsel in die brief aan die Efesiërs gevind kan word, en laastens is die merktekens kursories openbarings-histories getoets volgens die briewe aan die sewe gemeentes in Openbaring. Die bevindings wat gemaak is kom op die volgende neer: die kerk in die eerste eeue, volgens die merktekens van die kerk, het sy identiteit vanuit haar oorsprong missionêr geïdentifiseer en daarom was die merktekens in hulle gerigtheid op die aktiwiteit (taak) van die kerk steeds missionêr, om uitdrukking te gee aan die missionêre identiteit van die kerk. Die vier merktekens van die kerk, naamlik eenheid, heiligheid, katolisiteit en apostolisiteit, behoort steeds bepalend vir die kerk se missionêrekklesiologiese identiteit te wees.

The four marks of the church in the Confession of Nicea as guidelines in an ecclesiological discours. The research centred around the four concepts in the Confession of Nicea namely unity, holiness, catholicity and apostolicity. The question investigated was whether these four marks could serve as guidelines for an ecclesiological discourse. In this article attention was firstly paid to the Confession of Nicea about the marks of the church, next it was looked into whether these marks could in principle be traced in the letter to the Ephesians. Lastly, the the marks were tested in a revelation-historically, cursory manner and in accordance with the letters to the seven congregations in Revelations. The conclusions reached amounted to the following: during the earliest centuries and/or ages the church identified, in accordance with the marks of the church, its identity as being missionary. That is why the marks in their alignment to the activities of the church, are still missionary, to give expression to the missionary identity of the church. The four marks of the church namely unity, holiness, catholicity and apostolicity should still be determining the missionary ecclesiological identity of the church.

\section{Inleiding}

Verskillende teoloë het hulle in hul ondersoek na die identiteit van die kerk toegespits op die merktekens van die kerk. Onder hulle is Küng (1976:263-359); Moltmann (1977:337-361); Du Plooy (1982:121-184); Van Engen (1991:25-179); Scudieri (1997:66-77); Link (1999:239-262) en Dulles (1999:14-28). Al bogenoemde navorsers se ondersoeke is gefokus op die betekenis van die frase 'ek glo aan een, heilige, algemene en apostoliese kerk' in die Geloofsbelydenis van Nicea. Daar is verdere ruimte om die merktekens as rigtingwysers in die ekklesiologiese diskoers te ondersoek.

Die ondersoek in hierdie artikel sentreer rondom die volgende vier begrippe, naamlik eenheid, heiligheid, katolisiteit en apostolisiteit. Daar bestaan ' $n$ besondere verhouding tussen Christus as Hoof en die kerk as liggaam. Die liggaam is instrumenteel die plek waar versoening plaasvind. Die vertikale versoening met God deur Christus word horisontaal in die liggaam 'n werklikheid. Waar hierdie versoening in gehoorsame roepingsvervulling plaasvind, word die misterie van die eenheid ' $n$ sigbare manifestasie aan die wêreld van die Hoof se dienende heerskappy wat alle verskeurdheid herstel, sodat Hy alles in almal kan wees. Volgens Van Engen (1991:56) en Gnilka (aangehaal deur Floor 1995:86) het die kerk as $\pi \lambda \eta \dot{\rho} \omega \mu \alpha$ [veelkleurig] van Christus 'n spesifieke taak om die liefde en vrede van Christus te proklameer - nie as magsmiddel nie, maar as instrument. Christus wil die ganse skepping in al sy fasette deurdring met die seëninge van sy heerskappy. Daarom mag die kerk nooit ophou om te roep, uit te nooi en nader na Hom te trek nie. Die kerk is betrokke by die $\pi \lambda \eta \dot{\rho} \omega \mu \alpha$ [veelkleurig] van alle dinge, deur verkondiging van die Woord. Nie net die kerk moet gevul word nie, maar 'alle dinge' (Van Engen 1991:56). 
As liggaam van Christus is die doel en bestemming van die kerk dus in haar $\pi \lambda \eta \dot{\rho} \omega \dot{\mu} \alpha$ [veelkleurig] te vind, kwalitatief op sy eie vervulling en kwantitatief op die uitbreiding van die volheid na die wêreld.

In Christus, as Hoof van sy liggaam, sy kerk, trek alles saam. $\mathrm{Hy}$ is as Hoof oor alles gestel, maar die kerk het Hy in beginsel volgemaak (vervul) met alles wat in God is. Die wêreld moet dit nog hoor en sien. Dít is die kerk se missionêre taak. Ekklesiologies is die kerk missionêr in vervulling van haar roeping op aarde. Die verhouding tussen Hoof en liggaam gee dus uitdrukking aan 'n missionêre ekklesiologie, wat die identiteit van die kerk bepaal.

Met bogenoemde as vertrekpunt, in ooreenstemming met Nicea se merktekens van die kerk, kan die volgende vier stellings as uitgangspunt van die verdere beredenering dien:

- Daar is ' $n$ geheimenisvolle (misterie-) eenheid wat sigbaar word.

- Die Evangelie van versoening word verkondig in getroue roepingsvervulling, wat uitdrukking gee aan heiligheid.

- In die liggaam (kerk) waar versoening 'n horisontale werklikheid word, kom mense saam uit alle volke (Jood en heiden), wat uitdrukking gee aan die katolieke gestalte van die kerk.

- Die versoening wat werklikheid word, is die vrug van getroue roepingsvervulling wat uitdrukking gee aan die apostoliese gestalte van die kerk.

Die navorsingsvraag in hierdie artikel is of hierdie vier merktekens as riglyne in ' $\mathrm{n}$ ekklesiologiese diskoers kan dien. Hierdie vier merktekens het immers hulle basis onder andere in die brief aan die Efesiërs en het ' $n$ belangrike rol vervul in die vroeë Christelike kerk en so neerslag gevind in die belydenis van Nicea. Eerstens word een van die oudste belydenisse van die kerk, die belydenis van Nicea, bespreek om so na te gaan hoe die kerk in die eerste eeue haar identiteit verstaan het. Die ondersoek is ' $n$ literêre ondersoek. Voorts probeer die ondersoek kursories vasstel of die begrippe eenheid, heiligheid, katolisiteit en apostolisiteit as merktekens en aanduiding van die identiteit van die kerk, reeds in beginsel in die brief van Paulus aan die Efesiërs gevind kan word. Die boodskappe van Johannes aan die sewe gemeentes in Klein-Asië (Op 2 \& 3) sal as openbarings-historiese kontrole aangewend word, om na te gaan of die merktekens eenheid, heiligheid, katolisiteit en apostolisiteit ook by die gemeentes gevind kan word as aanduiding van die identiteit van die kerk.

\section{Merktekens van die kerk volgens Nicea}

\section{Histories}

Tydens die eerste Konsilie van Konstantinopel (381 n.C.) is, ná die byvoeging van ' $\mathrm{n}$ vierde merkteken, die apostoliese (naas die eenheid, heiligheid en katolisiteit), die sogenaamde Niceano-Constantinopolitanum as belydenis van die kerke wat daar verteenwoordig was, aanvaar. By die vierde Konsilie van Chalcedon (451 n.C.) is die Geloofsbelydenis van Nicea, saam met die uitbreiding van Konstantinopel, as belydenis vir die hele Christelike kerk aanvaar. Die laaste byvoeging by die teks van die Geloofsbelydenis van Nicea is gedoen in 589 n.C., toe die Derde Nasionale Sinode van Toledo sitting geneem het. By die artikel wat oor die Heilige Gees handel, is die sogenaamde Filioque [en van die Seun] bygevoeg. Die teks wat ons vandag gebruik, lui dat die 'Gees van die Vader en van die Seun' uitgaan. Omdat die besluit nie deur die ekumeniese konsilie geneem is nie, maar deur 'n nasionale sinode in die Westerse Kerk, wou die Oosterse Kerk nooit die byvoeging aanvaar nie. Uiteindelik sou die Westerse (RoomsKatolieke) en die Oos-Ortodokse Kerke in 1054 finaal skeur, onder andere as gevolg van die Filioque (Dreyer 2000:5, 8).

\section{'n Geloofsbelydenis}

Wanneer die begrippe een, heilig, katoliek en apostolies gebruik word om die aard en karakter van die kerk (die merktekens) te beskryf, moet dit sigbare kwaliteite van die kerk wees wat werklik bestaan (Dulles 1999:126). Wanneer abstrak oor die eienskappe nagedink word, verloor dit voeling met die werklikheid waarin hulle bestaan. Die enigste wyse waarop 'n kerk geëvalueer kan word, is volgens dit wat gesien kan word (Getz 1975:16). Maar die kerk ís nie dit wat in die werklikheid op die oog af gesien kan word nie; sy is in beginsel een maar tog in die praktyk verdeeld, heilig maar tog vol sonde, universeel maar tog plaaslik, apostolies maar tog vasgevang in tradisies van bepaalde tye. Die merktekens is deel van die kerk se belydenis omdat hulle uit die geloof ontstaan het en maak daarom deel uit van ' $\mathrm{n}$ belydenis van die Drie-enige God (Moltmann 1977:337). Die vier eienskappe is daarom nie net merktekens alleen nie, maar ook geloofsverklarings (Watson 1978:334; Clowney 1995:71; Naude 2002:50-53).

Die eenheid van die kerk is nie in die eerste plek 'n eenheid van haar lede nie, maar ' $n$ eenheid met (in) Christus, wat sy kerk saamgeroep het en in alles met hulle meeleef. Net so is die heiligheid van die kerk ' $n$ heiligheid van (in) Christus, wat Hy deur regverdigmaking aan sy kerk gee. Die katolisiteit is geloof aan die heerskappy van Christus. Die apostolisiteit van die kerk kan alleen verstaan word binne die raamwerk van Christus se sending in hierdie wêreld.

\section{Uitdrukkings van hoop}

As die kerk afhanklik is vir haar bestaan van Christus se Messiaanse sending en die eskatologiese gawe van die Gees, is haar merktekens ook Messiaanse uitdrukkings. In dié mate is hulle ook uitdrukkings van hoop (Moltmann 1977:339; Clowney 1995:72).

Die eenheid van die kerk is ' $\mathrm{n}$ merkteken van die verlossing, omdat dit ' $\mathrm{n}$ Ou-Testamentiese belofte is wat in vervulling gegaan het. In die Ou Testament is die belofte van herstel 'n belofte met ' $n$ deurlopende lyn. In Christus gaan die belofte in vervulling wanneer Hy Jode, Grieke, heidene, base en knegte, mans en vrouens nuwe mense maak van 'n nuwe koninkryk. Die ware eenheid van die kerk is nie in die eerste plek 'n eenheid van die lede van die kerk nie, maar die lede 
van die kerk is die vrug van die versoeningswerk van Jesus Christus as Hoof (Gal 3:26-27).

Ooreenkomstig hierdie belofte is heiligheid deel van die komende heerlikheid wat die aarde sal vul. Die Heilige van Israel sal sy mense verlos. As die kerk heilig genoem word in die Nuwe Testament, beteken dit dat sy deel geword het van Christus se nuwe skepping wat tot stand gebring word deur die Heilige Gees (Pont 2002:5, 8). Die vrug van Christus se regverdigmaking is die gemeenskap van heiliges (Rom 3:30).

Die kerk is katoliek in soverre haar deel is van die katolisiteit van die komende koninkryk (Labuschagne 2002:8). Die katolisiteit is nie die vrug van die kerk se uitreik na die wêreld nie, maar primêr vrug van Christus se afbreking van grense (Ef 2:13-14). Sy is katoliek omdat sy 'Hoof' 'n katolieke hoof oor alles en almal is (Ef 1:22-23). Die kerk se apostolisiteit is deel van die begin van die nuwe Messiaanse era (Botha 2002:8), wat ingelei is deur die uitstorting van die Heilige Gees (Hand 1:8).

Die vier merktekens van die kerk moet daarom gesien word as:

[M]essianic predicates of the church in the perspective of the coming kingdom, for which it exists and which in the church acquires form and testimony. As the church of the coming kingdom of God, the church is bound to be the one, holy, catholic and apostolic church. (Moltmann 1977:339)

\section{Roeping tot aksie}

As die merktekens van die kerk verklarings van geloof en hoop is, lei dit onteenseglik tot aktiwiteit. Omdat die kerk in Christus een is, móét dit ook een wees (Küng 1976:273). Diegene wat hulle eenheid in Christus vind, moet die eenheid soek. Die een volk en/of liggaam en/of mens van die een koninkryk, moet die fondasies vir eenheid in die wêreld lê. Omdat die kerk in Christus heilig is, moet lidmate hulle sonde bestry en moet hulle lewens geheilig word deur geregtigheid. Mense word opgeroep tot die weg van bekering om so die Koninkryk van God binne te gaan (Heitink 2007:195). As gevolg daarvan dat hulle geheilig is deur die Gees, moet hulle in alles by die nuwe skepping pas. Omdat die kerk deur Christus oop is vir die wêreld, moet sy (die kerk) katoliek wees en oral van die nuwe koninkryk getuig. As die kerk van die Gees, is die één kerk die verenigende kerk in die wêreld. Die heilige kerk is die kerk wat heilig. Die katolieke kerk is die draer van vrede en só die allesomvattende kerk. Die apostoliese kerk is deur die Evangelie die vrymakende kerk in die wêreld, deur verkondiging van die Evangelie van Christus (Moltmann 1977:339-340; Van Engen 1991:65-70).

\section{Gereformeerde onderskeiding}

As gevolg van die selfregverdigende gebruik van die merktekens deur die Rooms-Katolieke Kerk (Clowney 1995:101), was die Hervormers daarvan oortuig dat ' $n$ onderskeid behoort gemaak te word tussen kenmerke ${ }^{1}$ van

\footnotetext{
1.Skrywers gebruik die terme kenmerke en merktekens inkonsekwent. In hierdie artikel word met 'kenmerke' aangedui die gereformeerde aanduiding van Woord diens en tug en met 'merktekens' die Nicaanse aanduidings van: een, heilig, katoliek en apostolies.
}

die ware kerk (te wete suiwer verkondiging van die Woord, suiwer bediening van die sakramente en kerklike tug, wat eers later sou bykom) en merktekens (notae) van die kerk. Bavinck (1986:1895-1901) en Berkouwer (1976:13) toon aan dat die verskil tussen kenmerke en merktekens noodsaaklik was om 'n onderskeid tussen die ware en valse kerk aan te dui (kyk Calvyn [1559] 1991:1282). Dit was nooit die bedoeling van die Hervormers om 'n nuwe Christelike groep (kerk) wat tot stand gekom het, te definieer nie, maar om aan die bestaande begrippe wat die merktekens verwoord (een, heilig, katoliek en apostolêr) 'n dieper inhoud te gee (Link 1999:258). Berkhof (1979) vat die diepste bedoeling met die reformatoriese onderskeiding tussen kenmerke en merktekens soos volg saam:

The decisive point is this: the Church is and must remain subject to the authority of Christ, to the voice of her Lord. And in this subjection she is tested by Him. That is the common Reformation motive underlying the notae. (bl. 409)

Die Hervormers het met hierdie onderskeid hulleself probeer onderskei van die Roomse Kerk, wat institusionele krag verleen het aan die merktekens (Clowney 1995:101; Watson 1978:334). Die verkondiging van die Woord en die praktiese toepassing van die sakramente is die kerk in aksie, wat in praktyk uitleef wat die Woord as fondament het. Johannes Calvyn het net hierdie eerste twee kenmerke geformuleer en tug van toepassing gemaak by die sakramentsgebruik (later het tug 'n selfstandige kenmerk geword [Clowney 1995:101]). Net soos die drie kenmerke nie teenoor die vier merktekens geplaas kan word nie, kan die vier merktekens nie afgespeel word teen die drie kenmerke nie. 'n Kerk waarin die Woord suiwer verkondig word en die sakramente reg toegepas word, ís die een, heilige, katolieke en apostoliese kerk. Die reformatoriese kenmerke toon slegs van binne wat die tradisionele merktekens van buite aantoon (Moltmann 1977:341). Sonder die suiwer verkondiging van die Woord, kan daar nie 'n ware kerk wees wat die ware eenheid in Christus verkondig nie. Sonder die ware gemeenskap van gelowiges aan die nagmaal en in die doop, het die kerk geen katolisiteit nie. In die lig hiervan kan ook gesê word dat sonder eenheid, heiligheid, katolisiteit en apostolisiteit as merktekens, daar ook nie 'n suiwer verkondiging van die Woord en sakramentsbediening kan wees nie. Die vier merktekens funksioneer in die lig van die twee kenmerke, en andersom.

'n Belangrike vraag met die oog op hierdie ondersoek is of die Hervormers se onderskeiding van kenmerke en merktekens bygedra het daartoe dat ' $n$ missionêre ekklesiologie uitgebou kon word. Van Engen (1991:63), Moltmann (1977:341) en Murray (2001:111) vind geen probleme met die Hervormers se onderskeiding nie; trouens hulle is eenstemmig daarin dat daar ' $n$ belangrike wisselwerking tussen die onderskeiding, kenmerke en merktekens (notae) kan wees. Die resultate met die toepassing van die nuwe onderskeiding van die drie kenmerke deur Hervormers, word egter nie deur almal positief gewaardeer nie. Burger (2001:100) toon aan dat die drie kenmerke meer te doen het met die bediening van 
die kerk as met die taak van die kerk. Hy trek voorts drie kontoere om die taak van die kerk (die taak van die kerk kan as ' $n$ aanduiding van ekklesiologiese kontoere gesien word, hoewel Burger dit nie so definieer nie) aan te dui, naamlik:

- om kennis van God, die lewende God wat ons in Jesus Christus leer ken het, te versprei

- om die genade en die liefde wat ons van die Here ontvang het na ander deur te gee, deur dit te leef

- om mense te wees wat, soos ons God, glo in reg en geregtigheid en billikheid vir almal en wat wil help skep aan ' $\mathrm{n}$ wêreld waarin ons meer hiervan sien. (Burger 2001:100)

Wat Burger aantoon, naamlik dat die drie kenmerke van die Hervormers fokus op 'bediening' wat na binne gerig is en nie soseer op roepingsvervulling in die wêreld (die taak) waarin God sy kerk geplaas het nie, word baie meer krities beoordeel deur Moltmann en Van Engen.

\section{Moltmann (1977) sê:}

We cannot therefore merely give the marks of the church bearings that tend in an inward direction, understanding them in the light of word and sacrament; we must to the same degree give them an outward direction and see them in reference to the world. They are not merely important for the internal activities of the church; they are even more important for the witness of the church's form in the world. The marks of the church will then become confessional signs in the conflicts which today are really splitting and dividing mankind. Let us therefore extend the ecclesiology of tradition, which is orientated towards unity, into an ecclesiology oriented towards conflict in the world situation of today. (bl. 342)

Van Engen (1991) sê:

Unfortunately, soon after the Reformers, the Reformation 'marks' themselves became means for destroying unity, true holiness, and catholicity. Luther and John Calvin originally intended these marks to be dynamic, inclusive means by which greater unity, holiness, and catholicity might be achieved. Sadly, the children of the Reformation stressed the other, darker side of these marks - their introverted, exclusivistic tendency. Increasingly in post Reformation Protestantism they also lost their self examining, dynamic function. (bl. 63)

\section{'n Nuwe uitkyk}

Befaamde en kritiese teoloë soos Küng (1976:266-269), Berkhouwer (1976:Hfst3), Dulles (1999:27), Berkhof (1979:409) en Barth (1936:27-28) vra almal vir ' $n$ herevaluering van die vier merktekens. Hulle is van oortuiging dat die merktekens tegelyk gawe en opdrag aan die kerk is. Die uitleef van so 'n benadering kan nuwe missionêre moontlikhede vir die kerk oopmaak. Scudieri (1997:66-77) skryf 'n artikel met die strekking dat hierdie historiese belydenis van die Christendom missionêre gereedskap is, omdat dit sy ontstaan gehad het in die missionêre tydvak van die kerkgeskiedenis. Vandag, sê Scudieri (1997:66), het die belydenis vasgevries geraak in die kerk se tradisies. Herontdekking van hulle missionêre krag, met spesifieke verwysing na die merktekens, sal nuwe lewe in die kerk bring (Jones 1958:200). Die ondersoek na die betrokke inhoudelike in Efesiërs en Openbaring se boodskappe, sal hierdie standpunt moet nagaan. Meegaande skets onderstreep die siening dat die Reformatoriese eienskappe (Woordverkondiging, sakramentsbediening en tug) van die kerk ' $n$ belangrike plek inneem in die taak na binne, terwyl die merktekens (eenheid, heiligheid, katolisiteit en apostolisiteit) uitdrukking gee aan die missionêre taak van die kerk.

Waarvoor daar gepleit word (en hierdie artikel wil 'n pleitroep byvoeg), is dat daar weer kreatief gewerk moet word om hierdie waardevolle merktekens, merktekens in aksie te maak. Selfs die onderskeiding tussen gawe en opdrag is nie toereikend nie, omdat daarin self ook 'n gevaar bestaan dat die kerk steeds na binne gerig word (Van Engen 1991:67). Daar moet konstruktief na buite gekyk word, na die wêreld waar die kerk haar taak moet volbring. Moltmann (1977:341-342) pleit dat die merktekens 'n getuienis moet wees van die kerk se gerigtheid op die wêreld. Van Engen (1991:68) stel voor dat die merktekens gesien moet word as 'four planetary orbits of the Church's missionary life in the world' (vgl. Figuur 1).

Die vier merktekens in aksie kan soos volg opgesom word:

- Die een kerk van Jesus Christus moet gesien word as 'n verenigende krag in die wêreld.

- Die heilige kerk van Jesus Christus moet gesien word as 'n heiligende (vernuwende ) krag in die wêreld.

- Die katolieke kerk van Jesus Christus moet gesien word as 'n versoenende krag in die wêreld.

- Die apostoliese kerk van Jesus Christus moet gesien word as 'n verkondigende krag in die wêreld.

Só gesien sal die vier merktekens nie net aktiwiteite van die kerk wees nie, maar haar identiteit definieer as missionêrekklesiologies. Die kerk sal dan wees die verenigende, heiligende (vernuwende), versoenende en proklamerende (verkondigende) aktiwiteit van Jesus Christus in die wêreld (Van Engen 1991:70). Die missionêre roeping van die kerk sal dan nie net iets addisioneel wees wat bygevoeg word by die

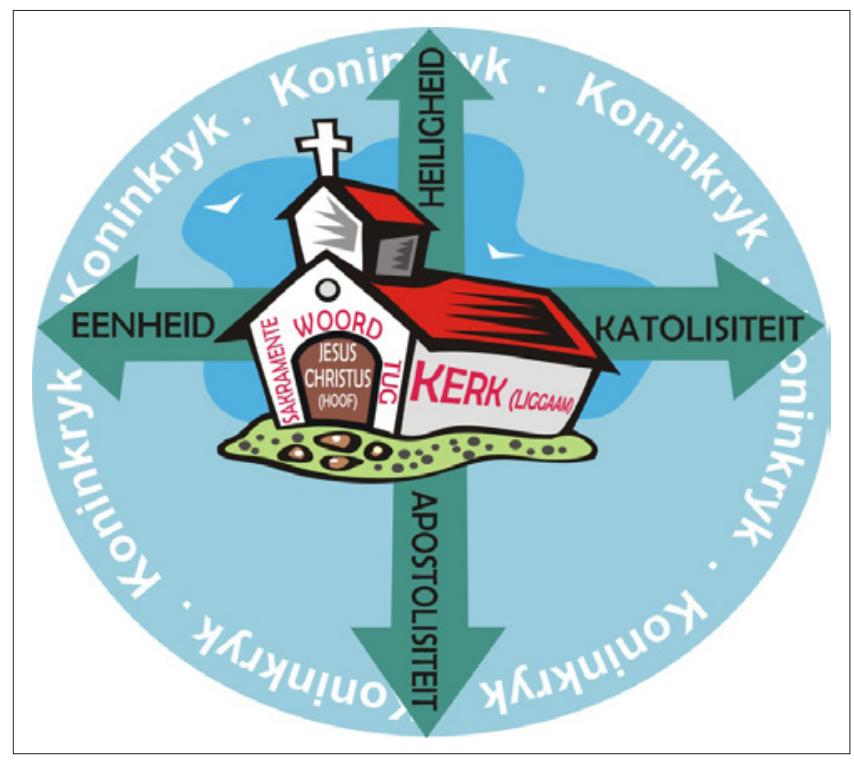

FIGUUR 1: Gemodelleerde voorstelling. 
essensie van kerkwees nie. Die essensiële karakter van die plaaslike kerk sal dan missionêr wees.

\section{Voorlopige gevolgtrekkings}

Die kerk in die eerste eeue het, eerstens, volgens die merktekens van die kerk, haar identiteit vanuit haar oorsprong missionêr geïdentifiseer en daarom is die merktekens in hulle gerigtheid op die aktiwiteit (taak) van die kerk steeds missionêr, om uitdrukking te gee aan die missionêre identiteit van die kerk.

Tweedens is die kenmerke van die ware kerk (Woordverkondiging, suiwer bediening van die sakramente en toepassing van tug) volgens die gereformeerde ekklesiologie, steeds waardevolle onderskeidingstekens vir die kerk se gerigtheid na binne.

Die kenmerke van die ware kerk het derdens 'n eensydige na-binne gerigtheid tot gevolg gehad, wat die funksionering van die merktekens in die gereformeerde kerkgemeenskappe as 'n missionêre ekklesiologie aan bande lê.

Laastens moet die merktekens van die kerk by hernuwing ontdek word as Skriftuurlik in oorsprong en missionêr in hulle gerigtheid.

\section{Merktekens volgens Efesiërs}

Die ondersoek in hierdie onderdeel van die artikel is daarop gerig om te probeer vasstel of die begrippe een(heid), heilig(heid), katoliek (katolisiteit) en apostolêr (apostolisiteit) as merktekens en aanduiding van die identiteit van die kerk, reeds in beginsel in die brief van Paulus aan die Efesiërs, gevind kan word. Dit sal die hipotese bevestig dat die kerk in die eerste eeue die merktekens van die kerk, en daarom ook die identiteit van die kerk, afgelei het van, onder andere, die brief van Paulus aan die Efesiërs. Dit sal ook die hipotese bevestig dat die brief aan die Efesiërs in sy wese ' $n$ missionêre geskrif is.

In die ondersoek na merktekens van die kerk (eenheid, heiligheid, algemeenheid en apostolisiteit) gaan kortliks gefokus word op:

- $\quad$ eenheid (Ef 4:1-16)

- heiligheid (Ef 4:17-24)

- katolisiteit (algemeenheid) (Ef 3:1-13)

- apostolisiteit (Ef 3:1-13).

\section{Eenheid (Ef 4:1-16)}

Paulus skryf in Efesiërs op diepgaande wyse oor die eenheid van die kerk (Floor 1995:143). In Efesiërs 4 verklaar hy:

Daar is net één liggaam en net één Gees, soos daar net één hoop is waartoe God julle geroep het. Daar is net één Here, één geloof, één doop, één God en Vader van almal: Hy wat oor almal is, deur almal werk en in almal woon. (Ef 4:4a-6b)

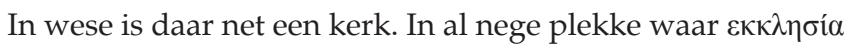
[kerk] in Efesiërs voorkom, staan dit in die enkelvoud. Die 'eenheid' van die kerk is 'n gelowige aanvaarding. Dit is iets wat deur God gegee en nie deur mense tot stand gebring is nie. Die model van die eenheid is die Gees, die Here, die Vader. Die eenheid van die kerk vloei uit die Drie-enige God (De Klerk 2001:65):

- Die Gees is die model vir die eenheid; in sy Persoon en deur sy inwoning in en hoopgewing aan die kerk .

- Die Here Jesus is model vir die eenheid omdat Hy die één en enigste Hoof van die kerk is.

- Die Vader is model vir die eenheid omdat daar één God is, al sou die heidene baie gode hê.

Die eenheid van die kerk is ' $n$ geloofsbelydenis, omdat dit in die gebrokenheid en verskeurdheid van die wêreld nie 'n empiries waarneembare werklikheid is nie. Hierdie belydenis het praktiese implikasies. Omdat gelowiges die eenheid van die kerk aanvaar, beywer hulle hulle om daardie eenheid te bewerk (Ef 4:1-3). Paulus roep die kerk op om hulle roeping baie ernstig te neem in die strewe na eenheid (Ef 4:1, 3; Garland 1979:517-527). Die kwaliteit van kerkwees is geleë in haar bestaan as missionêre kerk, wat tegelyk 'n oortuigende manifestasie is van die realiteit van God se verlossing in Christus én van sy missionêre uitreiking om húlle wat oortuig word in te bring as deel van die nuwe eenheid wat besig is om te realiseer (Hahn 1965:148-152). Die eenheid is nie geleë in ' $n$ na-binne gerigtheid van eensgesinde entoesiaste nie. Hier is 'n liggaam van apostels, profete, evangeliste, herders en leraars wat mekaar bystaan in die proklamasie van die Evangelie in die wêreld rondom hulle. Dit is dié liggaam wat ontplof het in aktiwiteit ten tye van die vroeë kerk en na al die nasies toe gegaan, gepreek, onderrig, gedoop en hulle dissipels gemaak het (Matt 28:19-20).

Die oorkoepelende doel van die eenheid word weergegee in Efesiërs 4:13-16. Hier is sprake van groei tot 'n groter eenheid deur die byvoeging van lede tot die liggaam (numeriese groei) groei deur geestelike ontwikkeling van die lede van die liggaam wanneer hulle hulle gawes aanwend ter wille van die wêreld (organiese en geestelike groei); groei na 'n groter impak van die liggaam van Christus in die wêreld na wie die kerk gestuur is (groei in diakonia en/of diens) en 'n verdiepte groei in die verstaan van die heerskappy van Christus in die kerk en ' $n$ vasstaan sonder om meegesleur te word en ontwortel te word deur allerhande leringe (teologiese groei - Ef 4:14).

Die missionêre opdrag van die kerk en eenheid vloei organies in mekaar in Paulus se siening van die kerk. Die verhouding tussen Christus as Hoof van die liggaam loop uit op 'n eskatologiese werklikheid: '... sodat Hy die kerk in volle heerlikheid by Hom kan neem, sonder vlek of rimpel of iets dergeliks, heilig en onberispelik' (Ef 5:27; vgl. ook Op 21:9-10, 25-26). Die kerk vind die vervulling van haar missionêre roeping in die wêreld deur te wees wie sy is: 'n verenigende krag in die wêreld.

\section{Heiligheid (Ef 4:17-24)}

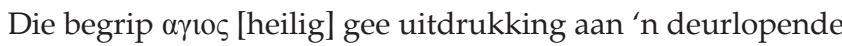
tema in Efesiërs (vgl. Ef 1:1-14, 3:14-21, 4:17-5:5 \& 5:6-6:20). 
Reeds vroeg in die brief stel Paulus heiligheid as doel van die grootste gawe (indikatief) wat ons van God ontvang het, die uitverkiesing (Floor 1995:51). Die opdrag (imperatief) 'om heilig te lewe' loop soos 'n goue draad regdeur die brief. In Efesiërs 4:17-24 word die heidense leefwyse, wat die kenmerk van hulle vroeëre lewe was, aangedui as 'n lewe wat op 'n ramp afstuur (Ef 4:17-19) - teenoor die nuwe leefwyse in Christus, wat afstuur op ' $n$ pragtige nuwe lewe (Ef 4:20-21) en wat ' $n$ toonbeeld is van God se heiligheid (Ef 4:22-24; De Klerk 2001:78).

Dwarsdeur Efesiërs staan heiligheid uit soos 'n baken. Die brief is gerig aan heiliges (Ef 1:1) en tot aan die einde van die brief speel heiligheid ' $n$ dominante rol. Paulus roep sy lesers op tot ' $n$ heilige lewenswandel (Ef 5:1-21), om lig te wees in die duisternis (Ef 5:8-14), om toegerus te wees om die stryd teen die Bose en bose geeste in die lug aan te pak (Ef 6:10-18). Die heiligheid van die kerk is ' $n$ indikatief en imperatief, ' $n$ gawe en doel van God vir sy kerk (Ef 1:1-14). Die lewe van die gelowige is daartoe in staat om die ongelowige op te roep om uit die geestelike dood op te staan deur die krag van God (De Klerk 2001:95).

Daar is ' $n$ verband tussen die lewe van die gemeente en hoe elke 'nuwe mens' die liggaam van Christus verteenwoordig in die wêreld. Hoe elke lid van die liggaam in die samelewing leef, spanning tussen verskillende bevolkingsgroepe (rassisme) oplos, die nood van mense met MIV of VIGS hanteer, 'n kultuur van geweld en korrupsie aanspreek, die nood van armoede en werkloosheid verlig, standpunte in politiek inneem, die omgewing bewaar of sport beoefen, reflekteer op die liggaam van Christus in die wêreld. Paulus wil hê die kerk, as liggaam van Christus, moet weet dat die wyse waarop hy heiligheid in sy persoonlike lewe uitleef, ' $n$ uitdrukking is van die heiligheid van die liggaam van Christus. Die kerk se heiligheid trek uiteindelik saam in die stryd teen die boosheid van die bose magte van die sondige wêreld (Ef 6:12), wat staan teenoor die heilige mag van God. Dit is 'n stryd van twee koninkryke, dié van God en dié van Satan. Die kerk (plaaslik en universeel) is God se verteenwoordigers in die stryd. Die oorwinning in die stryd is vervulling van die missio Dei deur die missio ecclesia. Die liggaam van Christus is in hierdie stryd 'n missionêre gemeenskap. Die stryd word oorwin deur die uitlewing van die identiteit van die kerk as heilige gemeenskap. Eers wanneer die kerk die volle wapenrusting van God aantrek, is sy gereed om nie net ' $n$ verskil te maak nie, maar die wêreld te verander deur die beoefening van ware missionêre heiligheid (Van Engen 1991:54).

Ware heiligheid is groei in liefde (Ef 3:17b-19). In Efesiërs 3:14-21 teken Paulus heiligheid as krag van die Gees wat die innerlike sterk maak (Ef 3:16); wanneer Christus in die gelowige woon (Ef 3:17) en hy so vol word van God (Ef 3:19). Wat is dan die werklike kern van God se heilige teenwoordigheid in en deur die kerk? Liefde! Liefde het veral 'n 'sodat-karakter' (De Klerk 1987:87). Christus het Homself oorgegee om sy gemeente te heilig, sodat hy sy gemeente by Hom kan neem in heerlikheid sonder vlek of rimpel of iets dergeliks (Ef 5:27). Die Efesiërs word ook opgeroep om 'in die liefde gewortel en gegrondves te wees' sodat hulle sal verstaan 'hoe wyd en ver en hoog en diep die liefde van Christus strek' (Ef 3:17-19). Liefde is God se krag in hierdie wêreld.

Die kerk vind die vervulling van haar missionêre roeping in die wêreld deur te wees wie hy is: ' $n$ heiligende (vernuwende) krag van God in die wêreld.

\section{Katolisiteit en apostolisiteit (Ef 3:1-13)}

Katolisiteit (die reikwydte van die Evangelie) en apostolisiteit (opdrag van verkondiging) as begrippe lê baie naby mekaar. Apostolisiteit funksioneer reeds in Efesiërs in die praktyk, maar dit is eers na die afsluiting van die apostelperiode dat die opdrag aan die kerk in die algemeen sou gaan. Sonder apostolisiteit is katolisiteit nie moontlik nie. Waar die Evangelie verkondig word, brei dit uit onder almal.

Die perikoop in Efesiërs 3:1-13 kan in twee gedeel word. Die eerste (Ef 3:1-6), handel oor die inhoud van die geheimenis. Die inhoud van die geheimenis is dat die Evangelie aan mense verkondig word wat nie-Jode is. Die reikwydte van die evangelie gaan nou oor volks- en kultuurgrense heen. Die tweede deel (Ef 3:7-13) handel oor die verkondiging van die geheimenis. Die fokus in dié gedeelte is dat die Evangelie verkondig word.

Die kerk is van die Hoof afhanklik vir haar lewe, identiteit en sending in die wêreld [missio ecclesiae]. Christus is opgewek uit die dood en gestel aan die regterhand van God die Vader, verhewe bo enige reël en gesag, krag of heerskappy (Ef 1:21). Alles is aan Hom ondergeskik. Hy is aan die kerk gegee as Regeerder oor alle dinge en Hy is die Hoof van die liggaam, die kerk. Christus is wêreldhoof oor alle geskape dinge, maar as wêreldhoof woon $\mathrm{Hy}$ in die kerk as liggaam en laat dit lewe.

Wanneer hierdie kosmiese Christologie toegepas word op die liggaam van wie Christus Hoof is, ontwikkel 'n verrykende katolisiteit (universaliteit) (Van Engen 1991:55). Die gelowige aanvaar in die geloof die universaliteit van die kerk, omdat dit erken word as uitdrukking van die universele intensie van God in Jesus Christus (Ridderbos 1973:23). Deur vir Hom 'n volk uit te kies, wil God na die hele wêreld uitreik. Deur Israel as verteenwoordiger van alle volke uit te kies, het God nooit sy oog weggevat van alle nasies nie.

Die kerk bely haar universaliteit in Jesus Christus en wil dit om dié rede toepas op die hele wêreld (Ef 2:1-22). Omdat die 'genade en goedheid wat Hy in Christus aan ons bewys het' (Ef 2:7) bedoel is vir almal (Ef 1:23), mag die kerk nooit ophou om te roep, uit te nooi, nader te trek, die wat nog nie naby is nie. Die katolieke kerk se werkterrein is al die hoofweë en kronkelpaadjies van die wêreld, met besondere uitnodiging. Die katolieke kerk is 'n totale óóp gemeenskap, met sy deure wawyd oop vir almal. Die katolieke kerk kan nie sy universaliteit laat inperk deur eksklusivisme, 
of dit van sosiale, ekonomiese, ras-, geslags-, kulturele of nasionalistiese aard is nie (Van Engen 1991:56). Die katolieke kerk is missionêr en gestuur na almal (apostolêr) omdat die Hoof van die kerk 'alles in almal vervul' (Ef 1:23).

Omdat gelowiges die universaliteit van die kerk bely en nastreef om dit te verwesenlik, moet hulle verstaan dat hulle lewens as Christene 'n uitdrukking moet wees van die katolieke aard van die kerk (Ef 2:13-22). Gelowiges kan hulleself as wêreldgerigte Christene begin sien omdat die 'middelmuur van skeiding' (Ef 2:14) afgebreek is. Nou is alle etniese en sosiale grense oorwin in die volheid van die één liggaam, versoen deur die dood en opstanding van elke gelowige in Christus (Ef 2:16-17). Gelowiges is nie meer 'ver van God af nie, nie bywoners nie, maar medeburgers van die gelowiges en lede van die huisgesin van Christus' (Ef 2:19), binne die gebou wat God besig is om op te rig (Ef 2:20-22). Dit beteken nie die uitwis van etniese en kulturele grense nie, maar die aanvaarding daarvan as deel van die rykdom wat God aan sy kerk gegee het. Verskille word verstaan as gawes van God.

Soos wat die kerk in universaliteit groei, kom die geheimenis aan die lig wat God aan die 'apostels en profete bekend gemaak het' (Ef 3:1-13). As gevangene van die universele intensie van Jesus Christus, is Paulus draer van hierdie geheimenis; dat mense 'wat nie Jode is nie, saam met ons deel van die volk van God en lede van die liggaam van Christus is' (Ef 3:6). Die inhoud van die geheimenis is 'de volken zijn in Christus rechtens en metterdaad en effektief aanvaard door God' [Die volkere is in Christus regtens, volledig en effektief deur God aanvaar (Floor 1995:129 [outeur se eie vertaling]).

Elke gelowige bely met sy lidmaatskap aan die kerk dat hy en/of sy ingetrek is in die kerk, sodat die kerk al meer en meer universeel kan wees. Dan word hulle uitgestuur om dissipels te maak van ander (Matt 28:19) sodat die kerk haar apostoliese karakter kan uitbou, maar terselfdertyd getrou kan wees aan sy hoër roeping. Die kerk is nie 'n eksklusiewe klub van bevoorregtes of ' $n$ rusplek om weg te kom van die spanning van die wêreld nie. Gelowiges is byeen geroep in die kerk sodat hulle ander kan inbring in die koninkryk van genade, '... sodat God ook in die tye wat kom, sou laat sien hoe geweldig groot sy genade is deur die goedheid wat Hy in Christus Jesus aan ons bewys het' (Ef 2:7).

Die katolisiteit en die apostolisiteit kom tot uitdrukking waar die kerk in gehoorsaamheid aan haar Hoof, Jesus Christus, die boodskap van die versoening al verder en dieper die wêreld indra. Waar die kerk die geheimenis van die versoenende eenheid uitdra oor lands-, kulturele- en sosiale grense heen, vind daar geografiese, kulturele, numeriese, etniese en sosiale groei plaas. Hierin lê die geheimenis van God se doel vir alle mense, soos geopenbaar aan Paulus (Ef 3:6-8). Hierin kom die volle missionêre karakter van die kerk tot uitdrukking. Die kerk groei na binne en na buite (katoliek), waar die Evangelie verkondig word (apostolêr).

As gevangene, deur God se beskikking, is Paulus uitgestuur na die nie-Jode (Ef 3:1) (katoliek). As draer van die misterie word ook mense wat nie Jode is nie, saam met ons deel van die volk van God en lede van die liggaam van Jesus Christus (Ef 3:6) (apostolaat). Hy moet aan die heidene die onpeilbare rykdom van die kosmiese heerskappy van Christus (Ef 1:22, 3:8) verkondig, sodat dit uiteindelik 'deur die kerk' aan die 'bose magte in die hemelruim' bekend gemaak kan word (Ef 3:10-11). Die kerk vind die vervulling van haar missionêre roeping in die wêreld deur nie net deel te wees van die katolieke kerk op aarde nie, maar deur die verkondiging van versoening (die geheimenis) en deur ook 'n apostolêre kerk te wees, wat só 'n versoenende en verkondigende krag in die wêreld kan wees.

\section{Voorlopige konklusies}

Eerstens, die vervulling van die kerk se missionêre roeping in die strewe na eenheid, heiligheid, katolisiteit en apostolisiteit in Efesiërs vind op 'n Skriftuurlike basis plaas.

Tweedens, deur te wees wie die kerk is, naamlik een, heilige, katolieke en apostoliese kerk in die wêreld, vervul hy sy missionêre roeping as ' $n$ verenigende, transformerende (vernuwende), versoenende en verkondigende $\mathrm{krag}$ in die wêreld.

\section{Merktekens openbarings-histories getoets volgens briewe aan die sewe gemeentes in Openbaring}

Die briewe in Openbaring kan moontlik as kontrole dien om die funksionering van ' $n$ missionêre ekklesiologie in die Nuwe Testament na te gaan. Die fokus sal veral op die brief aan die Efesiërs val (Op 2), wat waarskynlik aan die ander gemeentes in Klein-Asië gestuur is, net soos elkeen van die briewe in Openbaring 2 en 3. Nikolainen (vgl. Minnear 1966:90) kom in 'n ondersoek na Johannes se ekklesiologiese beskouing tot die gevolgtrekking dat Johannes se beskouing dieselfde is as dié van Paulus en in feite ' $n$ goeie samevatting is van die Nuwe Testament se siening van ekklesiologie. Wat met die kerk gebeur, het tussen Paulus se skrywe aan die Efesiërs en dié van Johannes, kan nie 'n verskil in die NuweTestamentiese ekklesiologiese beskouing maak nie.

Die vraag wat hier na vore kom is of die selfidentifikasie van Christus in die briewe aan die gemeentes van Klein-Asië, in hulle verhouding tot konteks, hoopgewing en oproep tot bekering, kan dien as kontrole vir die voorkoms van die merktekens van die kerk (eenheid, heiligheid, katolisiteit en apostolisiteit) in Efesiërs. Daar word slegs enkele afleidings uit die brief van Johannes aan Efese gemaak en oorsigtelik getoets aan die briewe aan die ander ses gemeentes (vir volledige beredenering vgl. Schalekamp 2005:154 e.v.).

Die afleiding wat uit Christus se selfidentifikasie gemaak kan word, is dat die eenheid van die kerk in die verhouding met Christus as Hoof weerspieël word, wat die universele kerk in sy hand hou. Die heiligheid van die kerk word weerspieël in die verhouding Hoof-en-liggaam, waar die Hoof in sy opbouende besorgdheid sy kerk voortdurend 
wys op hulle roepingsvervulling (in Efese se geval in stryd teen valse leer). Christus se liggaam, die kerk, se opdrag in hierdie wêreld is om ligdraers te wees in 'n donker wêreld deur die voortdurende uitdra van die Evangelie. Vanuit hierdie selfidentifikasie blyk die katolisiteit en apostolisiteit as merktekens van die kerk.

Die afleidings wat uit die lewe van die gemeente in Efese gemaak kan word is dat daar in die positiewe bemoediging van Efesiërs 'n sterk ekklesiologiese element na vore kom in samehang met die selfidentifikasie van Christus. Die Efesiërs het volhard in die uitdra van die Evangelie en hulle nie laat meesleur deur negatiewe elemente en valse leer nie. Die ekklesiologiese element wat na vore kom is dié van apostolisiteit as merkteken. Die werke van gelowiges is vir Christus belangrik, daarom maak Hy sy oë nie toe vir die Efesiërs se tekortkominge nie, maar roep Hy hulle weer op tot 'n heilige lewenswandel van liefde. 'n Ekklesiologiese element kom na vore, naamlik heiligheid as merkteken.

Die afleidings wat uit die gee van hoop aan die gemeente in Efese gemaak kan word, is dat die eenheid van die kerk weerspieël word in die verhouding van Christus as Hoof, wat die universele kerk in sy hand hou. Heiligheid van die kerk word weerspieël in die verhouding Hoof-en-liggaam, waar die Hoof in sy opbouende besorgdheid sy kerk voortdurend wys op hulle roepingsvervulling (in Efese se geval in stryd teen valse leer). In die positiewe bemoediging (oproep tot bekering) van Efesiërs kom 'n sterk ekklesiologiese element na vore, in samehang met die selfidentifikasie van Christus. Die Efesiërs het volhard in die uitdra van die Evangelie en hulle nie laat meesleur deur negatiewe elemente en valse leer nie. Die ekklesiologiese element wat na vore kom is dié van apostolisiteit as merkteken. Die werke van gelowiges is vir Christus belangrik, daarom maak Hy sy oë nie toe vir die Efesiërs se tekortkominge nie, maar roep Hy hulle weer op tot ' $n$ heilige lewenswandel van liefde. ' $n$ Ekklesiologiese element kom na vore, naamlik heiligheid as merkteken.

Struktureel vertoon al sewe briewe dieselfde patroon, naamlik (1) 'n opdrag om te skryf aan die engel van die gemeente (2) 'n profetiese selfidentifikasie van die opgestane

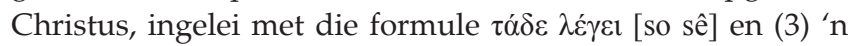
eskatologiese belofte, wat somtyds verbind word met ' $n$ waarskuwing en 'n oproep om te hoor wat die Gees vir die gemeentes sê. Dieselfde inhoudelike patroon is in al sewe briewe te vinde, soos dit aangetoon is ten opsigte van Efese, naamlik 'n selfidentifikasie van Christus, die huidige konteks van die gemeente, hoopgewing met die oog op die nabye en verre toekoms en 'n finale oproep.

Al vier die elemente van die briewe se inhoud is in die ander ses briewe, net soos in die brief aan die Efesiërs, van ekklesiologiese belang en kan met verdere navorsing moontlik die merktekens van eenheid, heiligheid, katolisiteit en apostolisiteit na vore bring. Die slotoproep plaas die eskatologiese perspektief (nabye en verre toekoms) in ' $n$ ernstige lig. Bekering is moontlik en noodsaaklik.

\section{Slot}

Die kerk in die eerste eeue het, volgens die merktekens van die kerk, haar identiteit vanuit haar oorsprong missionêr geïdentifiseer en daarom is die merktekens in hulle gerigtheid op die aktiwiteit (taak) van die kerk steeds missionêr.

Die kenmerke van die ware kerk, Woordverkondiging, suiwer bediening van die sakramente en toepassing van tug, volgens die gereformeerde ekklesiologie, is steeds waardevolle onderskeidingstekens vir die kerk se gerigtheid na binne.

Die kenmerke van die ware kerk het 'n eensydige na-binnegerigtheid tot gevolg gehad, wat die funksionering van die merktekens in die gereformeerde kerkgemeenskappe as ' $n$ missionêre ekklesiologie aan bande lê.

In die ondersoek na die identiteit van die kerk volgens merktekens van die kerk, is bevind dat die merktekens, soos bely in die belydenis van Nicea (451 n.C.), die missionêr ekklesiologiese identiteit van die kerk saamvat. Dit vind 'n Skriftuurlike basis in die brief van Paulus aan die Efesiërs (60 n.C.) en die merktekens in die briewe van Johannes aan die gemeente van Efesiërs (95 n.C.) (en moontlik ook in die ander ses briewe) en was rigtinggewend in die verhouding van die Hoof tot sy liggaam, die kerk, ten spyte van kontekstuele veranderinge en verskille wat daar tussen gemeentes bestaan het.

In die lig van die eerste paragraaf kan aangetoon word dat die vier merktekens van die kerk, naamlik eenheid, heiligheid, katolisiteit en apostolisiteit, steeds bepalend vir die kerk se missionêr-ekklesiologiese identiteit behoort te wees.

\section{Erkenning Mededingende belange}

Die outeure verklaar dat hulle geen finansiële of persoonlike verbintenis het met enige party wat hulle nadelig kon beïnvloed in die skryf van hierdie artikel nie.

\section{Outeure se bydraes}

Beide M.E.S. (Noordwes-Universiteit) en B.J.d.K. (NoordwesUniversiteit) het volledig gelyke bydraes aan die artikel gehad.

\section{Literatuurverwysings}

Barth, K., 1936, The church and the churches, Eerdmans, Grand Rapids, MI.

Bavinck, H., 1986, Our reasonable faith: A survey of Christian doctrine, transl. H. Zylstra, Eerdmans, Grand Rapids, MI.

Berkhof, H., 1979, Christian faith, An introduction to the study of the faith, transl. G.F. Callenbach, Eerdmans, Grand Rapids, MI.

Berkouwer, G.C., 1976, The church, transl. J.E. Davison, Eerdmans, Grand Rapids, MI.

Botha, S., 2002, 'Ons glo een kerk, gegrond op die leer van die apostels', Die Hervormer 95(3), 5, 8

Burger, C.W., 2001, 'n Ondersoek na die denke oor sekere voorvrae van die vak Praktiese Teologie in Suid-Afrika, RGN Uitgewers, Pretoria.

Calvyn, J., [1559] 1991, Institusie van die Christelike Godsdiens, transl. H.W. Simpson, 4 vols., Calvyn Jubileum Boekefonds, Potchefstroom.

Clowney, E.P., 1995, The Church, Intervarsity Press, Downers Grove, IL. 
De Klerk, B.J., 1987, 'Die Heilige Gees en die verhouding Skriflesing, prediking en gebed in die erediens', Ph.D. Proefskrif, PU vir CHO, Potchefstroom.

De Klerk, B.J., 2001, Fokus op Efesiërs, Deputate Jeugsorg van die Nasionale Sinode GKSA, Potchefstroom. (Soeklig-reeks).

Dreyer, W.A., 2000, 'Die Geloofsbelydenis van Nicea', Die Hervormer 93(7), 5, 8.

Dulles, A., 1999, 'The church as one, holy, catholic, and apostolic', Evangelical Review of Theology 23(1), 14-28.

Du Plooy, A. Le R., 1982, 'Kerkverband, 'n Gereformeerd-kerkregtelike studie', Th.D. Proefskrif, Departement Praktiese Teologie, PU vir CHO, Potchefstroom.

Floor, L., 1995, Efeziërs: Een in Christus, Kok, Kampen.

Garland, D.E., 1979, 'A life worthy of the calling: Unity and holiness, Ephesians 4:1-24' Review and Expositor 76, 517-527.

Getz, G.A., 1975, The measure of a church, Regal Books, Glendale, CA.

Hahn, F., 1965, Mission in the New Testament, SCM Press, London.

Heitink, G., 2007, Een kerk met karakter, Tijd voor heroriëntatie, Kok, Kampen.

Jones, J.A., 1958, 'The origin and marks of the church', Interpretation: A Journal of Bible and Theology 12, 194-203.

Küng, H., 1976, The church, 6th edn., Image Books, Garden City, NY.
Labuschagne, K., 2002, 'Die geloof aangaande die algemene kerk', Die Hervormer April, 5-8.

Link, C., 1999, Toward the future of Reformed Theology, Eerdmans, Grand Rapids, MI. Minnear, P.S., 1966, 'Ontology and ecclesiology in the apocalypse', New Testament Studies January, 89-105. http://dx.doi.org/10.1017/S0028688500017987

Moltmann, J., 1977, The church in the power of the Spirit, SCM Press, London.

Murray, S., 2001, Church planting, Herald Press, Pennsylvania.

Naude, P., 2002, 'Confessing Nicea today? Critical questions from a South African perspective', Scriptura 79, 46-53.

Pont, A., 2002, 'Ek glo ... 'n heilige kerk', Die Hervormer 94(22), 5-8.

Ridderbos, H., 1973, Paulus: Ontwerp van zijn Theologie, 3rd edn., Kok, Kampen.

Schalekamp, M.E., 2005, 'Missiones ecclesiae: 'n Missionêre visie en strategie in gemeentebou ten opsigte van multikulturele kerkplanting', Th.D. Proefskrif, Department Praktiese Teologie, Noord-Wes Universiteit, Potchefstroom.

Scudieri, R.J., 1997, 'The Creed of Nicea as a paradigm for mission', Missio Apostolica $5(2), 66-77$

Van Engen, C., 1991, God's missionary people, Baker Books House, Grand Rapids, MI.

Watson, D., 1978, I believe in the church, Hodder and Stouton, London. 